EPiC Series in Computing
Volume 63, 2019, Pages 170-181
$\begin{gathered}\text { Proceedings of 32nd International Conference on } \\ \text { Computer Applications in Industry and Engineering }\end{gathered}$

\title{
The use of social media by local governments: The case of Manabí's cantons in Ecuador
}

\author{
Gonçalo Paiva Dias ${ }^{1}$, Mariuxi Bruzza ${ }^{2}$, Manuel Tupia ${ }^{3}$ \\ ${ }^{1}$ ESTGA/GOVCOPP, Universidade de Aveiro, Rua Comandante Pinho e Freitas, 28 \\ 3750 - 127 Águeda, Portugal \\ ${ }^{2}$ Faculty of Hospitality and Tourism, University Laical "Eloy Alfaro" of Manabí, Ciudadela \\ Universitaria S/N, Manta, Ecuador \\ ${ }^{3}$ Department of Engineering, Pontificia Universidad Católica del Perú, Av. Universitaria 1801 \\ San Migue, Lima, Perú \\ gdp@ua.pt, mariuxi.bruzza@uleam.edu.ec, tupia.mf@pucp.edu.pe
}

\begin{abstract}
The use of social media as an instrument for public institutions to provide information and digital services to their citizens and promote their participation has become a common strategy in the scope of e-government. In this study, an empirical investigation of the diffusion of Facebook, Twitter, and YouTube among the local governments of the 22 cantons of the province of Manabí (Ecuador) is presented. In addition to portraying the adoption of social media by the local governments in the province, the results show that the Diffusion of Innovation (DOI) Theory can be used to explain the adoption process among the studied governments and that those can be classified according to the five DOI Theory's adoption categories: innovators; early adopters; early majority; late majority; and laggards.
\end{abstract}

Keywords: e-government, social media, local government, DOI Theory.

\section{Introduction}

In the scope of the National Electronic Government Plan 2018-2021 [1], the Ecuadorian Government actively promotes the development of e-government at the local level through the so-called Decentralized Autonomous Governments (DAG). In practice, according to this Plan, municipal DAG, or canton governments (hereinafter referred to simply as cantons or municipalities) are essential partners for developing the envisioned open, near, effective and efficient government. Nevertheless, because the first e-government initiatives are relatively recent in Ecuador, having occurred only since five years ago [2], and despite the progress made, there is still a wide margin for development. Indeed,

Q. Yuan, Y. Shi, L. Miller, G. Lee, G. Hu and T. Goto (eds.), CAINE 2019 (EPiC Series in Computing, vol. 63), pp. $170-181$ 
according to the UN annual ranking [3], the Ecuadorian government is in the 84/193 position, near the world average, still exhibiting relatively low scores both in the e-participation and online service indexes.

Among the tools used as mechanisms for the provision of information and digital services, social media have become basic instruments for interaction with citizens, constituting a key factor to achieve high levels of customer satisfaction and encouraging participation, with all the benefits that this brings [4][5]. The use of these Web 2.0 technologies obliges digital service provision initiatives to consider combining local government sites with information transparency portals and with social media in order to handle more complex services and not only static information [6]. A brief review of the state of the art of the use of social media in e-government shows the relevant role and impact of their use in the provision of transparency and in the reduction of the so-called digital gap as well as in the promotion of e-participation [7][8][9][10][11]. Moreover, the research of social media in the scope of local government is especially relevant in Ibero-America, because of the relatively recent democratization of that level of government and the social relevance of corruption [12].

Taking into consideration the above discussion, this study aims at understanding the diffusion of social media among the 22 Manabí's cantons. To the best of the authors' knowledge, this study is the first aiming at this goal in Ecuador. To achieve it, aggregated data on the cantons' official accounts on Facebook, Twitter, and YouTube was collected and analyzed. The results are discussed at the light of the Diffusion of Innovation Theory and constitute a first view of this theme in this country.

The remainder of this article is organized as follows: Section 2 briefly presents and characterizes egovernment development in Ecuador, the regional organization of the country, and the cantonal municipalities of the province of Manabí; Section 3 briefly presents the main aspects of the DOI Theory that are used to support the discussion; Section 4 introduces the methods used in the study; section 5 presents and discusses the results, including of the statistical analyzes that were undertaken; and, finally, Section 6 addresses the main conclusions and the future work.

\section{Setting the context}

The Government of Ecuador has established its Ministry of Telecommunications as responsible for implementing and supporting the National E-Government Plan 2018-2021. This plan succeeds the first National E-Government Plan that was published in 2015 and conducted under the responsibility of the National Secretariat of Public Administration [13].

\section{1 e-Government in Ecuador}

The current National E-Government Plan included among its strategic lines to bring public administration closer to the citizen. Within this plan, it was established that local governments (municipalities) would be the main points of inclusion to favor the active participation of the citizen and encourage e-readiness [1]. The main initiatives of this National Plan include open data, systems interoperability in public administration, transparency in information and costs involved in the provision of electronic government services, and interaction with citizens, among others [14].

Considering the relevance that local government assumes in this Plan, it is relevant to study local egovernment development in Ecuador. Some previous studies have previously addressed the provision of e-government through web portals at the local level in Ecuador [15][16][17][18][19][20][21], but not through social media, as proposed in this article. 


\subsection{The Manabí province}

The political organization of Ecuador includes the following powers: legislative function, executive function, judicial function, electoral function, transparency function and social control. Likewise, the territorial political organization of the country is as follows: regions, provinces, cantons and rural parishes. The Decentralized Autonomous Governments (DAG) are entities with their own executive and legislative authority [22]. They encompass rural parish boards, municipal councils, metropolitan councils, provincial councils and regional councils, among which, as previously mentioned, the municipalities or cantons assume the biggest prominence for e-government development.

\begin{tabular}{|c|c|c|c|c|}
\hline Canton & $\begin{array}{l}\text { Total } \\
\text { Population }\end{array}$ & $\begin{array}{l}\text { Population } \\
\text { Density }(\mathrm{p} / \mathrm{km} 2)\end{array}$ & $\begin{array}{l}\text { Internet } \\
\text { use }\end{array}$ & Main Economic Activities \\
\hline 24 de Mayo & 28,846 & 55.04 & 1,287 & Agriculture, forestry, hunting and fishing \\
\hline Bolívar & 40,735 & 75.85 & 4,480 & Livestock, agriculture and fishing \\
\hline Chone & 126,491 & 41.92 & 12,907 & trade, livestock, and agriculture \\
\hline El Carmen & 89,021 & 71.50 & 8,423 & Cultivation of pastures, plantain, cocoa, cocoa \\
\hline $\begin{array}{l}\text { Flavio } \\
\text { Alfaro }\end{array}$ & 25,004 & 18.61 & 972 & $\begin{array}{l}\text { Livestock, cultivation of coffee, cocoa, tagua, } \\
\text { banana, tropical fruits }\end{array}$ \\
\hline Jama & 23,253 & 40.44 & 1,980 & Shrimp, cattle, farming, artisanal fishing \\
\hline Jaramijo & 18,486 & 190.57 & 1,502 & Artisanal fishing, fishing industry \\
\hline Jipijapa & 71,083 & 50.08 & 7,538 & $\begin{array}{l}\text { Production of coffee, cocoa, handicrafts in clay, } \\
\text { straw toquilla, vine, cultivation, trade }\end{array}$ \\
\hline Junín & 18,942 & 77.00 & 1,214 & $\begin{array}{l}\text { Cana of sugar, coffee harvest, agricultural } \\
\text { products and livestock }\end{array}$ \\
\hline Manta & 226,477 & 1027.34 & 52,821 & $\begin{array}{l}\text { Industrial and artisanal fishing, tourism, various } \\
\text { industries. }\end{array}$ \\
\hline Montecristi & 70,294 & 95.76 & 7,415 & Agriculture, handicrafts, toquilla straw hat \\
\hline Olmedo & 9,844 & 38.90 & 448 & Agriculture and Livestock \\
\hline Paján & 37,073 & 34.35 & 1,674 & $\begin{array}{l}\text { Cultivation of cassava, cotton, mucus, rice, } \\
\text { fruits, coffee and tagua. }\end{array}$ \\
\hline Pedernales & 55,128 & 28.53 & 3,598 & Shrimp areas, coffee production, trade. \\
\hline Pichincha & 30,244 & 28.34 & 1,038 & Production of sugar cane and cassava starch. \\
\hline Portoviejo & 280,029 & 289.28 & 54,401 & Agriculture, trade. \\
\hline $\begin{array}{l}\text { Puerto } \\
\text { López }\end{array}$ & 20,451 & 48.69 & 2,204 & $\begin{array}{l}\text { Tourism, artisanal fishing, cultivation of corn, } \\
\text { coffee and plantain. }\end{array}$ \\
\hline Rocafuerte & 33,469 & 119.53 & 2,993 & Cultivation of rice, corn and cotton. \\
\hline San Vicente & 22,025 & 51.63 & 2,226 & $\begin{array}{l}\text { Artisanal fishing, agriculture, livestock, } \\
\text { tourism. }\end{array}$ \\
\hline Santa Ana & 47,385 & 46.36 & 2,919 & Agriculture, livestock, coffee, hats and mats. \\
\hline Sucre & 57,159 & 77.43 & 6,186 & $\begin{array}{l}\text { Export of shrimp, artisanal fishing, agriculture, } \\
\text { livestock. }\end{array}$ \\
\hline Tosagua & 38,341 & 101.70 & 3,172 & $\begin{array}{l}\text { Trade and cultivation of coffee, cocoa, banana } \\
\text { and cassava }\end{array}$ \\
\hline
\end{tabular}

Table 1: Cantonal Municipalities of Manabí 
Manabí is one of the 24 provinces in Ecuador. It is the third most populous province after Guayas and Pichincha (where the capital city of Quito is located) and its main economic activities include agriculture, forestry, livestock, fishing and tourism. It is located in the center of the Ecuadorian coast and is made up of 22 cantons whose basic population and economic data are presented in the Table 1 [23][24]. In the Table, Internet use refers to population of 5 years and over that used Internet in the last 6 months (accessed April 2019). Some of this information will be used in the analysis in Section 5.

\section{Diffusion and Innovation}

The Diffusion of Innovation Theory (DOI) [25], initially published in 1962, aims to explain the diffusion of innovation in society. Because e-government is as an innovation that must be adopted by both institutional providers and individual users, it makes sense to resort to this theory in order to explain e-government adoption and, in the specific case of this article, the adoption of social media by the Manabí municipalities.

The DOI Theory explains adoption as "the process in which an innovation is communicated thorough certain channels over time among the members of a social system" [25]. Four elements influence the diffusion of an innovation: innovation it-self, communication channels, time, and social system. It also defines five main constructs, named 'attributes of innovations', that, as perceived by individuals, are determinants of the rate of adoption of innovations: 'relative advantage'; 'compatibility'; 'complexity'; 'trialability'; and 'observability'. It also defines five adopter categories: innovators; early adopters; early majority; late majority; and laggards. Figure 1 shows the typical distribution of new adopters over time, considering the adopter categories.

While applying the DOI theory to organizations, as is the case in this article, three types of determinants of organizational innovativeness are identified: attitude towards change of the so called champion; internal characteristics of organizational structure (including centralization, complexity, formalization, interconnectedness, organizational slack, and size); and external characteristics of the organization (system openness). Among the previously mentioned determinants, the size of the organization is usually highly correlated with the adoption of innovation.

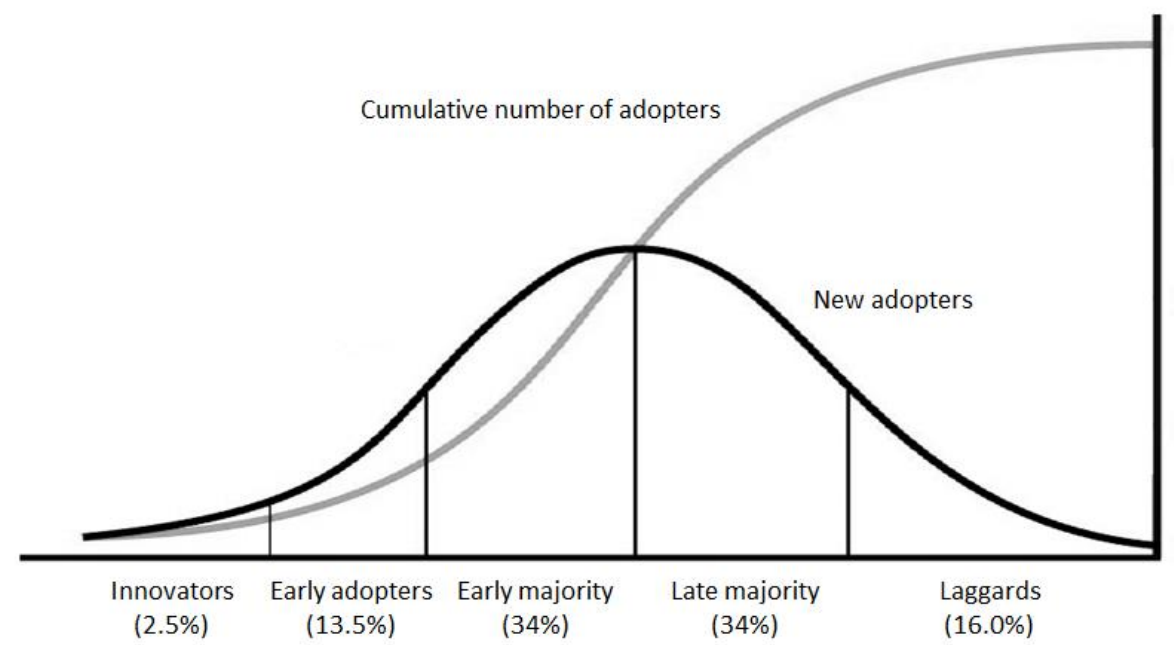

Figure 1: Categories of adopters according to the DOI Theory [25]. 


\section{Methods}

The empirical data that supports this study was extracted from the official accounts of the Manabí cantons in three well known social media applications.

- Facebook - collected data included the web address of the Facebook profile; if it was created as an institutional page; if it allows posting from followers; if it allows message sending; the number of people who liked the page, the number of page followers, and the date of last the publication;

- Twitter - collected data included web address of the Twitter profile, the start date of activities, the number of followers, the total number of tweets, and the date of latest tweet;

- YouTube - collected data included the web address of the YouTube channel; the channel opening date, the number of subscribers; the total number of views; and the date of publication of the latest video

The identification of the official social media accounts was performed by referring to the links to the selected social media applications in the Cantons' official websites. When these links were not available, the names of the Cantons were searched using the specific search engine of each social media application. In any case, the official nature of the account was verified taking into account its description and the published content.

\begin{tabular}{|c|c|c|c|c|c|}
\hline Municipio & Dirección web del perfil de Twitter & 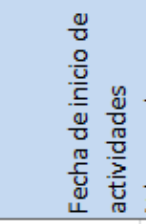 & 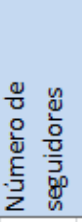 & 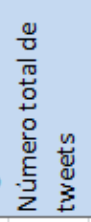 & 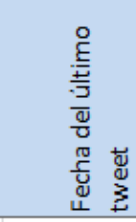 \\
\hline 24 DE MAYO & https://twitter.com/g 24demayo & 01-11-2014 & 783 & 880 & $13-12-2018$ \\
\hline BOLIVAR & https://twitter.com/CGCANTONBOLIVAR & 01-09-2016 & 3 & 0 & \\
\hline CHONE & https://twitter.com/GadChone & 01-03-2011 & 3199 & 11000 & $19-12-2018$ \\
\hline EL CARMEN & https://twitter.com/gadmelcarmen & $01-05-2015$ & 1002 & 2290 & $03-12-2018$ \\
\hline FLAVIO ALFARO & https://twitter.com/MunFlavioAlfaro & 01-04-2011 & 568 & 130 & $19-04-2018$ \\
\hline JAMA & https://twitter.com/municipiojama & 01-04-2014 & 1040 & 977 & $20-12-2018$ \\
\hline JARAMIJO & https://twitter.com/gadjaramijo & $01-02-2015$ & 257 & 308 & $19-12-2018$ \\
\hline JIPIJAPA & https://twitter.com/GAD Jipijapa & 01-04-2013 & 430 & 724 & $19-12-2018$ \\
\hline JUNÍN & https://twitter.com/GADJunin & $01-07-2012$ & 189 & 12 & $22-02-2018$ \\
\hline MANTA & https://twitter.com/municipio manta & $01-05-2014$ & 8026 & 16000 & $20-12-2018$ \\
\hline MONTECRISTI & https://twitter.com/gadmontecristi & 01-02-2015 & 1719 & 6350 & $20-12-2018$ \\
\hline OLMEDO & https://twitter.com/GadOImedo & $01-12-2015$ & 432 & 446 & 04-09-2018 \\
\hline PAJÁN & https://twitter.com/gadpajan & $01-06-2014$ & 313 & 44 & $02-06-2015$ \\
\hline PEDERNALES & https://twitter.com/gadmpedernales & $01-06-2014$ & 1798 & 3255 & $19-12-2018$ \\
\hline PICHINCHA & https://twitter.com/GADPichincha & 01-04-2013 & 973 & 1174 & $31-10-2018$ \\
\hline PORTOVIEJO & https://twitter.com/portoviejogad & 01-05-2014 & 7554 & 3146 & 07-12-2018 \\
\hline PUERTO LÓPEZ & https://twitter.com/gadpuertolopez & $01-06-2017$ & 126 & 70 & 11-07-2017 \\
\hline ROCAFUERTE & https://twitter.com/gadrocafuerte & $01-02-2017$ & 162 & 186 & $20-12-2018$ \\
\hline SAN VICENTE & https://twitter.com/Gad_San_Vicente & $01-12-2015$ & 803 & 3358 & $20-12-2018$ \\
\hline SANTA ANA & https://twitter.com/GADMCSantaana & $01-10-2015$ & 571 & 2753 & $12-10-2018$ \\
\hline SUCRE & https://twitter.com/GadSucre & $01-10-2014$ & 660 & 1327 & $19-12-2018$ \\
\hline TOSAGUA & https://twitter.com/gadmtosagua & $01-03-2012$ & 236 & 2678 & $29-06-2018$ \\
\hline
\end{tabular}

Figure 2: View of the instrument used to collect the data. 
The field work was performed during December 2018 with the support of a group of students from an Ecuadorian University located in the Manabí region. The methodology and instruments for data collection were previously explained in detail to all the participants by one of the authors. Each student assessed one Canton. All observations made by students were subsequently verified by the authors in order to identify and resolve any inconsistencies and ensure the validity of the results. A datasheet was developed and used to register and aggregate the observations made by students. Figure 2 shows the view of this instrument that was used to collect data from Twitter (note that the instrument is in Spanish).

\section{Results and discussion}

\subsection{Adoption and use}

Table 2 presents the percentage of Manabí cantons that have adopted each of the studied social media application, the percentage of the total number that are still active (having published at least one content item in the previous month), and the average number of content items published by day (only available for Twitter, considering only the cantons active in April 2019).

As can be observed, all Manabí cantons have adopted Twitter although only $83 \%$ have used in in the last year (with reference to the day data was collected) and $57 \%$ in the last month. In consequence, the average number of Twits published per day is low (considering the patterns for this social network) although its variance is high, with average values varying form 0.22 in the case of Jaramijó up to 9.45 in the case of Manta. In practice, the Facebook seems to be the most regularly used social media application with $83 \%$ of the cantons being active in the last month and $70 \%$ in the last year. The usage figures for YouTube are clearly lower than for Facebook and Twitter.

\begin{tabular}{lcccc}
\hline Social media & Adopters & Active in last year & Active in last month & Average activity \\
\hline Facebook & $96 \%$ & $83 \%$ & $70 \%$ & NA \\
Twitter & $100 \%$ & $83 \%$ & $57 \%$ & 2.4 items/day \\
YouTube & $91 \%$ & $39 \%$ & $26 \%$ & NA \\
\hline
\end{tabular}

Table 2: Adoption, continuity of activity and average activity

\subsection{Audience and audience determinants}

Table 3 presents the total and relative audiences (total audience divided by the total population). Total audience for by each canton was obtained by adding the numbers of followers in Facebook to the number of followers in Twitter and the number of subscribers in YouTube, alongside with Internet use and relative Internet use (population of 5 years and over that used Internet in the last 6 months divided by the total population of the canton). The cantons are order by decreasing relative audience. As is visible, cantons with bigger total audiences tend to be located in the upper part of the Table, which indicates that the cantons with more population are also those that have greater relative audience. Also, it seems that cantons with higher Internet use are usually those that have a greater percentage of population using it. 


\begin{tabular}{lrrrr}
\hline Canton & Total audience & Relative audience & Internet use & Relative internet use \\
\hline 24 de Mayo & 35,503 & 1,23 & 1287 & 0,04 \\
Manta & 156,526 & 0,69 & 52821 & 0,23 \\
Pedernales & 29,823 & 0,54 & 3598 & 0,07 \\
Olmedo & 4,852 & 0,49 & 448 & 0,05 \\
Tosagua & 12,278 & 0,32 & 3172 & 0,08 \\
Chone & 38,359 & 0,30 & 12907 & 0,10 \\
El Carmen & 25,545 & 0,29 & 8423 & 0,09 \\
Rocafuerte & 9,398 & 0,28 & 2993 & 0,09 \\
Portoviejo & 67,330 & 0,24 & 54401 & 0,19 \\
Jaramijó & 4,258 & 0,23 & 1502 & 0,08 \\
Pichincha & 5,122 & 0,17 & 1038 & 0,03 \\
Jama & 3,366 & 0,14 & 1980 & 0,09 \\
Montecristi & 9,661 & 0,14 & 7415 & 0,11 \\
Sucre & 7,835 & 0,14 & 6186 & 0,11 \\
Flavio Alfaro & 3,080 & 0,12 & 972 & 0,04 \\
Jipijapa & 7,353 & 0,10 & 7538 & 0,11 \\
Junín & 976 & 1214 & 0,06 \\
San Vicente & 1193 & 0,05 & 2226 & 0,10 \\
Santa Ana & 2108 & 0,05 & 2919 & 0,06 \\
Paján & 1,063 & 0,04 & 1674 & 0,05 \\
Bolívar & 930 & 0,03 & 4480 & 0,11 \\
Puerto López & 132 & 0,02 & 2204 & 0,11 \\
\hline Tabe 3: & 0,01 & &
\end{tabular}

Table 3: Total and relative audience in social media and the use of Internet.

In order to investigate possible relations between the total and relative audiences and the total population, the population density, the internet use and the relative inter-net use, two correlation studies were performed. The results of these studies are presented in Tables 4 and 5, respectively. There is a directed and significant correlation between the total audience and all the possible determinants. The same is not observed for the relative audience since non-significant correlations were found. Thus, the total audience tends to be greater in greater municipalities, more densely populated and with higher Internet use (both absolute and relative). Contrary, it seems that relative audiences may be being determined be other factors that were not tested in this study.

\begin{tabular}{ccccc}
\hline Total audience & Total population & Population density & Internet use & Relative internet use \\
\hline Coefficient & $0.815^{*}$ & $0.908^{*}$ & $0.869^{*}$ & $0.771^{*}$ \\
Sig. & 0.000 & 0.000 & 0.000 & 0.000 \\
$\mathrm{~N}$ & 22 & 22 & 22 & 22 \\
\hline
\end{tabular}

${ }^{*}$ The correlation is significant at the 0.05 level ( 2 extremities).

Table 4: Pearson correlations between total audience and possible audience determinants. 


\begin{tabular}{ccccc}
\hline Total audience & Total population & Population density & Internet use & Relative internet use \\
\hline Coefficient & 0.187 & 0.316 & 0.215 & 0.054 \\
Sig. & 0.404 & 0.152 & 0.338 & 0.811 \\
$\mathrm{~N}$ & 22 & 22 & 22 & 22 \\
\hline
\end{tabular}

Table 5: Pearson correlations between relative audience and possible audience determinants.

A complementary linear regression study was performed to assess to what extent population density (the independent variable most strongly correlated with total audience) can predict total audience. The resulting model is significant and explains $82.4 \%$ of the variability of total social media audience of Manabí's cantons, which is a very relevant result.

\subsection{Categories of adopters and determinants of adoption}

In order to identify categories of adopters, a study of the adoption year of Twitter and YouTube was performed. The same was not done for Facebook since the information on the date when the pages were created is not always available in that social network. Figures 3 and 4 depict the evolution of the number of Manabí's cantons adopting Twitter and YouTube, respectively, by year of adoption.

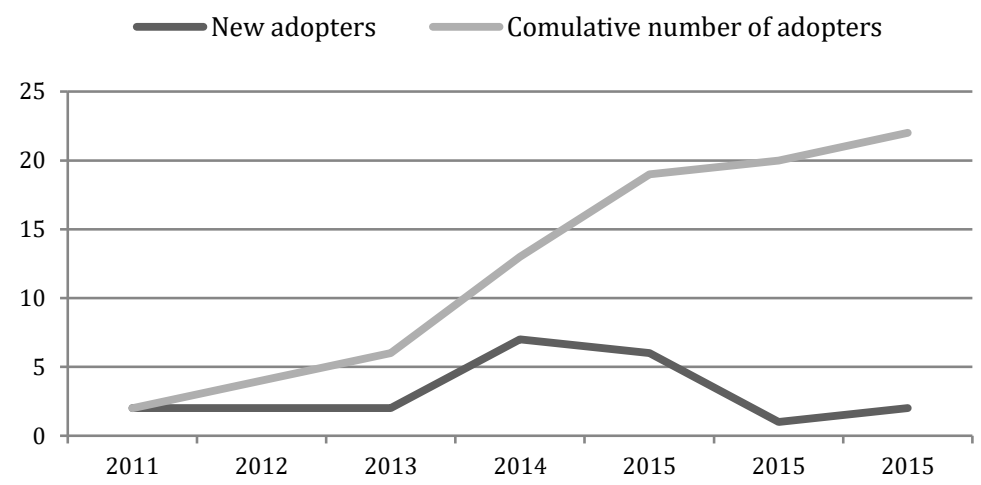

Figure 3: New adopters and cumulative number of adopters of Twitter, per year.

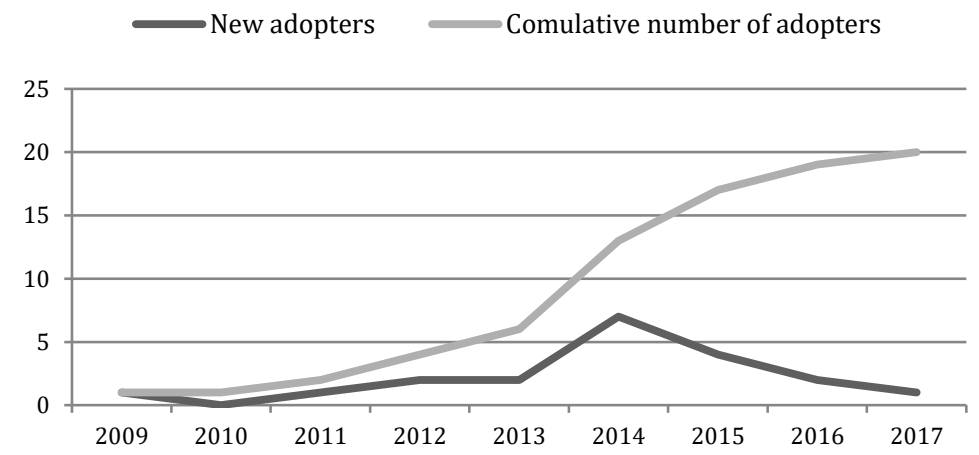

Figure 4: New adopters and cumulative number of adopters of Twitter, per year. 
As can easily be observed, these graphs have a striking similarity with the one presented in Figure 1. Thus, it seems that the adoption curves and, consequently, the adopter categories predicted by the DOI Theory are observable in the adoption of social media applications by the Manabí's cantons. Based on this observation, it is possible to distribute these cantons by the aforementioned categories, as is presented in Table 6. The presented percentages are compatible with those exhibited in Figure 1, namely taking into consideration the limited sample that is used in this study.

It is interest to note that, although the cantons that integrate each category for each social media application differ, there are some cantons that seem to be more innovative in general than others. The cantons of Chone, Tosagua, Jipijaja, and Pichincha, for example, integrate one of the two more innovative categories for both social media applications. On the opposite side, the cantons of Jaramijo, Montecristi, Olmedo, San Vicente, Santa Ana, Puerto López, and Rocafuerte integrate one of the two less innovative categories for both social media applications.

Considering the determinants of adoption, a T-tests was made to identify if there were significant differences between the means of the total population for the group of innovators and early adopters and the group of all other cantons (non-innovators and non-early adopters), both for Twitter and for YouTube. This was done because the total population is an indirect indication of the size of the municipality and, as discussed in Section 3 and according to the DOI Theory, the size of organizations is usually associated with higher innovativeness. Equal variances were not assumed in both cases based on previous Levene tests. Both studies were unfortunately inconclusive since no significant mean differences were found (See Table 7).

One of the possible reasons behind this might be related to the possibility that the social system through which the innovations are being diffused might be wider that the studied province, namely including all the municipalities of the country or even other types of organizations. Another possible reason might be related to a greater relevance of other determinants of organizational innovativeness, such as the attitude towards change of the champions or other internal or external characteristics of the cantonal municipalities.

\begin{tabular}{|c|c|c|c|c|}
\hline Category & Twitter & $\%$ & YouTube & $\%$ \\
\hline Innovators & Chone; Flavio Alfaro & 9,1 & 24 de Mayo & 4,5 \\
\hline Early adopters & $\begin{array}{l}\text { Junín; Tosagua; Jijijapa; } \\
\text { Pichincha }\end{array}$ & 18,2 & $\begin{array}{l}\text { Chone; El Carmen; Jipijapa; } \\
\text { Pichincha; Tosagua }\end{array}$ & 22,7 \\
\hline Early majority & $\begin{array}{l}24 \text { de Mayo; Jama; Manta; } \\
\text { Paján; Pedernales; Portoviejo; } \\
\text { Sucre }\end{array}$ & 31,8 & $\begin{array}{l}\text { Bolivar; Jama; Junín; Manta; Paján; } \\
\text { Pedernales; Portoviejo }\end{array}$ & 31,8 \\
\hline Late Majority & $\begin{array}{l}\text { El Carmen; Jaramijó; } \\
\text { Montecristi; Olmedo; San } \\
\text { Vicente; Santa Ana }\end{array}$ & 27,3 & $\begin{array}{l}\text { Flavio Alfaro; Jaramijó; Montecristi; } \\
\text { Olmedo; Puerto López; San Vicente }\end{array}$ & 27,3 \\
\hline Laggards & $\begin{array}{l}\text { Bolivar; Puerto López; } \\
\text { Rocafuerte }\end{array}$ & 13,6 & Rocafuerte; Santa Ana; Sucre & 13,6 \\
\hline
\end{tabular}

Table 6: Categories of adopters and percentage of Cantons in each category for Twitter and YouTube.

\begin{tabular}{lccc}
\hline & \multicolumn{3}{c}{ Total population } \\
\cline { 2 - 3 } Innovators and early adopters & Sig. $^{*}$ & Mean dif. & Std. err. dif. \\
\hline Twitter & 0.575 & $-14,575$ & 25,410 \\
YouTube & 0.925 & 2,394 & 25,034 \\
\hline
\end{tabular}

Table 7: Categories of adopters and percentage of Cantons in each category for Twitter and YouTube. 


\section{Conclusions and future works}

In this article we presented an empirical study of the adoption of Facebook, Twitter, and YouTube by the Manabí's cantons, Ecuador. The main conclusions are that although the three social media applications were adopted by the great majority of the cantons, a non-negligible percentage of them subsequently abandoned their use or do not use them regularly. Although Twitter is the only social media adopted by all cantons, Facebook seems to be the most regularly used. The use of YouTube is clearly lower than that for Facebook and Twitter.

Concerning the total audience of the cantons in social media, it is highly correlated with the cantons' population, population density, and Internet use. In contrast, the audience in percentage of population is not correlated with these factors, indicating that other determinants not captured by this study may be influencing the relative audience of the cantons in social media.

But the most interesting conclusion of this study is that the adoption curves of social media among the Manabí's cantons closely follow those that are predicted by the DOI Theory. This is a strong indication that this Theory can be used to explain social media adoption among municipalities in Ecuador. But in order to prove it, more empirical studies are needed, namely involving a bigger sample of Ecuadorian municipalities.

Thus, to extend the study presented in this article to other provinces of Ecuador is the natural continuation of the presented work. Other future works that arise from this study include the study of the determinants of early adoption, namely by conducting surveys and case studies. Those technics could also be used to verify if the elements that influence the diffusion of innovations and the attributes of innovations, as de-fined by the DOI Theory, are applicable to the diffusion of social media among local governments. To extend the study to other countries in Latin America and other regions of the globe is another direction for further studies.

\section{References}

[1] Ministerio de Telecomunicaciones y de la Sociedad de la Información, "Plan Nacional de Gobierno Electrónico | Gobierno Electrónico de Ecuador," 2018. [Online] Available: https://www.gobiernoelectronico.gob.ec/

[2] Presidencia de la República del Ecuador, "Decreto Ejecutivo № 149. Registro Oficial No. 146, Suplemento, December 18", 2013. [Online] Available: https://www.registrocivil.gob.ec/wpcontent/uploads/2015/04/DECRETO\%20No.\%20149.pdf

[3] United Nations, "E-Government Survey 2018," 2018, [Online] Available: https://publicadministration.un.org/egovkb/en-us/\#.W1DhEtUzq70

[4] A. Rexhepi, S. Filiposka and V. Trajkovik, "Social Networking for eGovernment: An Initial Assessment of Web 2.0 Tools Used by the Kosovo Central Government," in Proceedings of the 2nd International Conference on Recent Trends and Applications in Computer Science and Information Technology, RTA-CSIT, 2016, pp. 80-89.

[5] A. Anttiroiko, "Innovation in Democratic E-Governance: Benefitting from Web 2.0 Applications in the Public Sector," International Journal of Electronic Government Research. 6, 18-36 (2010).

[6] A. Magro, "A Review of Social Media Use in E-Government," Administrative Sciences. 2, pp. 148-161 (2012).

[7] F. Yusifov and R. Alguliyev, "Role of Social Networks in E-government: Risks and Security Threats," Online Journal of Communication and Media Technologies. 8, (2018). 
[8] A. Tursunbayeva, M. Franco and C. Pagliari, "Use of social media for e-Government in the public health sector: A systematic review of published studies," Government Information Quarterly. 34, pp. 270-282 (2017).

[9] R. Kaur and D. Saini, "Social Networking and e-Government: The Role \& Its Impact. International," Journal of Advanced Research in Computer Engineering \& Technology (IJARCET). 5, 811-819 (2016).

[10] M. Alryalat, N. Rana, G. Sahu, Y. Dwivedi and M. Tajvidi, "Use of Social Media in CitizenCentric Electronic Government Services," International Journal of Electronic Government Research. 13, pp. 55-79 (2017).

[11] M. Kassen, "E-Government Politics as a Networking Phenomenon," International Journal of Electronic Government Research. 13, pp. 18-46 (2017).

[12] G. P. Dias, "Fifteen years of e-government research in Ibero-America: A bibliometric analysis," Government Information Quarterly, article in press. DOI: 10.1016/j.giq.2019.05.008

[13] Secretaría Nacional de la Administración Pública del Ecuador, "Acuerdo No. 1063. Registro Oficial No. 312, Edición Especial, April 28," 2015. [Online] Available: https://www.registroficial.gob.ec/index.php/registro-oficial-web/publicaciones/edicionesespeciales/item/1826-edici\%C3\%B3n-especial-no-312

[14] Ministerio de Telecomunicaciones y de la Sociedad de la Información, "Desarrollo de Gobierno Electrónico en la Administración Pública de Ecuador, " 2018. [Online] Available: http:// www.telecomunicaciones.gob.ec/wp-content/uploads/2016/05/Programa-Nacional-deGobierno-Digital.pdf

[15] S. Oré and V. Lozada, "Maturity model for local E-Government: A case study," International Conference Proceeding Series, Vol. F128047, pp. 78-83 (2017).

[16] V. Morales and S. Bayona, "Municipal E-government in the provincial capitals of Ecuador," in Proceedings of 30th International Conference on Computer Applications in Industry and Engineering, ISCA, 2017, pp. 3-9.

[17] P. Henríquez-Coronel, J. Bravo-Loor, E. Díaz-Barrera and Y. Vélez-Romero, "E-Government and the Quality of Information in Web Portals of the GADM of Ecuador," in Proceedings of the International Conference on Information Technology and Systems, ICITS, 2019, Vol. 918, pp. 13-20.

[18] O. Bermeo-Almeida, M. Cardenas-Rodriguez, I. Ramirez-Sánchez, E. Ferruzola-Gómez and W Bazán-Vera, "Citizen participation in the use of the IRS portal that electronic government brings in the city of Milagro," in Proceedings of the 4th International Conference on Technology Trends, ICITT, 2018, Vol. 895, pp. 685-696.

[19] V. Morales and S. Bayona, "Determining Aspects in the Development of Municipal eGovernment," in Proceedings of the 5th International Conference on eDemocracy and eGovernment, ICEDEG, 2018, pp.158-165.

[20] P. Henríquez-Coronel, J. Bravo-Loor, E. Díaz-Barrera and Y. Vélez-Romero, "Open government and citizen participation in the web portals of Ecuador GADM," in Proceedings of the International Conference on Information Technology and Systems, ICITS, 2018, Vol. 721, pp. 1146-1155.

[21] G.P. Dias, G.P, M. Bruzza and M. Tupia, M, "Local e-government sophistication in Ecuador: the case of the Manabí province," in Proceedings of 6th International Conference on eDemocracy \& eGovernment, ICEDEG, 2019.

[22] Gobierno del Ecuador, "Constitución de la República del Ecuador,", Quito (2008). 
[23] Gobierno Provincial de Manabí Ecuador, "Cantones - Gobierno Provincial de Manabí Ecuador. Gobierno Provincial de Manabí Ecuador," Manabí (2018).

[24] Instituto Nacional de Estadisticas e Censos, "Ecuador en Cifras-Cifras por provincia,", 2019. [Online]. Available: http://www.ecuadorencifras.gob.ec/estadisticas/

[25] E. Rogers, Diffusion of innovations. New York: Free Press, 2003. 